IRSH 52 (2007), pp. I-20 DOI: I0.10I7/S0020859007003094

(C) 2007 Internationaal Instituut voor Sociale Geschiedenis

\title{
Humour and Social Protest: An Introduction*
}

\author{
MARJOLEIN' T HART
}

SUMmary: In the introduction to this volume, the author explains why social historians should study the relationship between humour and social protest in the past. The following questions are of interest. Under what conditions did laughter serve the cause of the protesters? How did humour strengthen social protest? And to what degree has humour been an effective tool for contentious social movements? Recent developments in the field of social movement theory regarding framing, collective identity, and emotions are combined with insights from humorology. A short account of the individual contributions follow: they range from the Zapatistas in Mexico to Vietnamese garment workers, from sixteenthcentury Augsburg to Madrid and Stockholm in the I990s. The findings point, above all, to the power of humour in the framing of political protest. Humour was used in quite different political opportunity structures, from open democratic societies to harsh repressive regimes. Often, humour furthered the development of the collective identity of a social movement, whereas in several cases humour acted as a powerful communication tool, serving as a true "weapon of the weak".

The atmosphere of this meeting is totally different from the old ones. Many things have changed certainly. People laugh, laugh more and more, more and more freely! We could however take a poll to find out how the words of $\mathrm{Mr}$ Deputy Premier, who reiterates his sincerity and his truthfulness, were received. The answer was unanimous: "The more the Deputy Premier insists on his sincerity, the more sincere our laughter becomes in the hall”.

(Solidarity Strike Bulletin no. 6, 27 August I980) ${ }^{\mathrm{I}}$

Humour and laughter can serve as a powerful tool in social protest. In ridiculing the representative of the government in the quotation above, a strong sense of unity was constructed among the strikers at the Lenin shipyard in Gdansk, Poland, during the very beginnings of the Solidarity

\footnotetext{
* I am grateful to Aad Blok, Dennis Bos, Pepijn Brandon, Bert Klandermans, and Giselinde Kuipers for their helpful comments and remarks. I thank Angèle Janse for her valuable help in editing this volume.

I. Quoted by Colin Barker, "Fear, Laughter, and Collective Power: The Making of Solidarity at the Lenin Shipyard in Gdansk, Poland, August 1980", in Jeff Goodwin, James M. Jasper, and Francesca Polleta (eds), Passionate Politics: Emotions and Social Movements (Chicago, IL [etc.], 200I) pp. I75-I94, I9I.
} 
Movement of the I980s. Great mirth was expressed in particular when Deputy Prime Minister Jagielski suggested that secret policemen needed more pay, because they often had to work overtime.

Yet protesters cannot always use humour. In strongly polarized settings, humour is one of the first victims. Seriousness and a strong emphasis on the righteousness of the claims inhibit laughter and joy. It is not without reason that revolutionaries (along with scientists) have been labelled humourless. ${ }^{2}$ Indeed, much social protest is fuelled by anger and fear, which leave little room for more frivolous thoughts. Humour is also a highly complicated tool: the sense of humour varies strongly among classes, groups, and time. ${ }^{3}$ In Western societies, the trait of "having a sense of humour" has only become widely accepted as a desirable norm for someone's character since the 1870 s or so. ${ }^{4}$ As humour is strongly context-bound, the risk that a joke will not get through is high. In highly variegated audiences, humour does not necessarily unite, it can also divide and exclude.

In the case above, the risk that the sympathizers of the Solidarity movement would not appreciate the humorous content was reduced as the context of the joke was clear, the interests of the protesters were obvious and well-defined, and the humour was directly related to the complicated negotiations with the government at hand. Even then many of the protesters were filled with enormous fear and the settings were extremely polarized.' How and why certain social movements can deal with humour, whereas others seem always more downcast and ponderous, is puzzling. This supplement aims to bring together a varied collection of examples of humour in social protest and tries to find out: (I) under what conditions laughter can serve the cause of the protesters; (2) how humour has strengthened social protest; and (3) to what degree humour has been an effective tool for contentious social movements. Of course, humour can also be deployed against social movements, yet this will only appear as a marginal theme. Rather, most contributions try to find out whether humour and social protest should be regarded as "comrades" or as "class enemies".

Up to now, social historians have hardly studied the relation between humour and social protest at all. But I think this issue now falls on fertile ground. The subject is facilitated by the rise in the study of humour during the last two decades. Humorologists nowadays have an International Society for Humour Studies and their own periodical, called Humor. Even

2. Hans Speier, "Wit and Politics: An Essay on Laughter and Power", American Journal of Sociology, I03 (1998), pp. I352-I40I, I358.

3. Giselinde Kuipers, Good Humor, Bad Taste: A Sociology of the Joke (Berlin [etc.], 2006), p. 230. 4. Rod A. Martin, The Psychology of Humor: An Integrative Approach (Amsterdam [etc.], 2007), p. 24.

5. Barker, "Fear, Laughter, and Collective Power", p. I86. On the dominance of "fear" in much of social protest, see also Jeff Goodwin and Steven Pfaff, "Emotion Work in High-Risk Social Movements: Managing Fear in the US and East German Civil Rights Movements", in Goodwin, Jasper, and Polleta, Passionate Politics, pp. 282-302, 286. 
though philosophers, social psychologists, and linguists still dominate the subject, social historians can profit from this new expertise too. Furthermore, in the study of social movements a recent emphasis has been put on the role of "framing", "collective identity", and "emotions", which allows us to put the research on humour and social protest in a wider and more suitable terminology. Also, in historical studies the bistoire des mentalités has produced approaches that can be useful in this regard.

The time seems ripe, then, to construct a social historian's combination of humorology with recent trends in social movement theory. First, I will evaluate the work of social historians in the field of humour and social protest. An account follows that stresses the findings by humorologists that matter in this respect. Then, several concepts of social movement theory are introduced, which will reappear again in the introductions of the individual contributions. At the end, I will return to the questions posed above.

\section{STUDIES ON HUMOUR AND SOCIAL PROTEST IN THE PAST}

The work of social historians on the minds and feelings of the past has become fashionable since the early i980s, not least through the impact of historical studies inspired by cultural anthropology. "Mentalities" and "emotions" have found a place in the new historiography on popular culture. ${ }^{6}$ Before, such topics had constituted only a marginal object of studies: even within the famous French Annales school only a few historians had followed up on the publication of Lucien Febvre's "La sensibilité et l'histoire" (I94I).7 Among historical sociologists, the reprint and translation of Norbert Elias's Über den Prozess der Zivilisation (1939) brought about renewed interest in how people strove to suppress their emotions over time. ${ }^{8}$ The study of historical sentiments was further stimulated by contributions in the Journal of Social History, among others. ${ }^{9}$

6. Clifford Geertz, “Thick Description: Toward an Interpretive Theory of Culture”, in idem, The Interpretation of Cultures: Selected Essays (New York, 1973), pp. 3-30; Michel Vovelle, Idéologies et mentalités (Paris, 1982); Peter Burke, Popular Culture in Early Modern Europe (London, 1978); Raphael Samuel and Gareth Stedman Jones (eds), Culture, Ideology and Politics (London 1982).

7. Lucien Febvre, "La sensibilité et l'histoire: comment reconstituer la vie affective d'autrefois?", Annales d'histoire sociale, 3 (194I), pp. 5-20; trans. Peter Burke in A New Kind of History: From the Writings of Lucien Febore (London, 1973), pp. I 2-26.

8. Norbert Elias, Über den Prozess der Zivilisation. Soziogenetische und Psychogenetische Untersuchungen (Basle, 1939); translated as The Civilizing Process (Oxford, 1994). For a combination of the histoire de mentalités with Elias's theory, see Robert Muchembled, L'invention de l'homme moderne. Sensibilités, moeurs et comportements collectifs sous l'Ancien Régime (Paris, 1988).

9. Barbara H. Rosenwein, "Worrying about Emotions in History", American Historical Review, 107 (2002), pp. 821-845, 824-826; Peter N. Stearns, "Social History Update: Sociology of Emotions", Journal of Social History, 22 (1989), pp. 592-599. 
Regarding the specific relationship between humour and social protest, most mentality histories so far have dealt with past carnival festivities and comic spectacles. In this respect, Mikhail Bakhtin's work on Rabelais and his World remains the most widely quoted of all. ${ }^{10}$ Bakhtin pointed to the powerful impact of humour in popular culture in the late medieval and early modern period. During carnivals and similar festive periods former ranks and hierarchies disappeared. All participants to the carnival were considered equal and free and familiar contacts were allowed between different social classes and positions. These ritual settings stressed the allhuman, all-joyous characteristics of life and opened the way for playful and undefined relationships. Furthermore, the festivals allowed the articulation of the idiomatic "world turned upside down", a funny and subversive way to play with established rules and hierarchies. ${ }^{\text {II }}$

During such events, political protest was possible, as long as it was done by joking. As the masquerades of religious festivals often hid the identity of the participants, members of the urban lower classes exploited these events to express their hostility towards the ruling oligarchy. Owing to the fact that such festive periods were limited in time, these protests carried little direct threat to the existing order. However, sometimes such carnivals got out of hand and ended up in outright rebellious movements. Emmanuel Le Roy Ladurie showed, in his work on the sixteenth-century revolt in Romans, France, for example, how following carnival dinners, "to eat the rich who had fattened themselves at the expense of the community", people took to the streets shouting, "Rich men, give the town back your dishonest gains!" ${ }^{2}$

The charivari was a related form of ritual manifestation. This mocking demonstration procedure was usually directed against neighbours to express public disagreement in familial, sexual, or marital matters. As such, it constituted part and parcel of popular culture. The authorities tolerated it: indeed, the charivari supported the process of social disciplining from below. However, charivari also ran the risk that political protest could gain an upper hand. For example, Charles Tilly showed how in I 833 the practice of charivari was turned into a direct political protest against the local authorities in Dijon. ${ }^{\mathrm{I}}$

Despite the risks that such events could get out of hand, political protest was usually allowed in these ritualized settings - or rather, the cost of suppressing it could turn out to be too high, as repression itself might

I0. M.M. Bakhtin, Rabelais and his World (Bloomington, IN, 1984); original version in Russian, 1965.

I I. Burke, Popular Culture, p. i 88.

I 2. Emmanuel Le Roy Ladurie, Carnival in Romans (New York, I979); see also Burke, Popular Culture, p. 204; M. Lane Brunner, "Carnivalesque Protest and the Humorless State", Text and Performance Quarterly, 25 (2005) pp. I36-I55, I39.

I3. Charles Tilly, The Contentious French (Cambridge, MA [etc.], i986), pp. 32-33. 
provoke an escalation of protest. Likewise, in royal courts, a jester could express critical thoughts about policies without fearing punishment by the ruler. His peculiar, ritualized position carried immunity. ${ }^{\mathrm{I}}$ Even nowadays professional comedians can present harsh and undesirable political truths through laughter: their position as official joke-makers makes them different from other political critics. After all, "fools" should not be taken seriously and replying in a serious manner to a joke is generally "not done". Is This is true for most of the more "democratic" societies, yet even in totalitarian regimes the authorities can act quite leniently towards social protest as long as the joking context is clear. ${ }^{16}$

Another ritualized setting that allowed for social protest was the published satire. Bakhtin devoted much of his study of Rabelais to this comic publication form - after all, the satire was the predominant medium of this sixteenth-century humanist author. Bakhtin pointed to its ability to express discontent at contemporary political events by invoking popularfestive, elementary imaginary. ${ }^{17}$ Early modern satirists escaped repression, as they were never explicitly clear about the object of their wit, even though the butt was often unmistakable to the public at large. In exposing and criticizing socio-political life, the satire of the early modern period is not so much unlike the caricatures and cartoons of our own days. In caricaturing power, it is the joking content that renders these communication methods so extremely successful. ${ }^{8}$

\section{HUMOROLOGY AND THE POWER OF THE JOKE}

In general, humorologists stress the role of jokes as a peculiar kind of communication strategy, peculiar due to the ambiguity of humour. For example, political jokes mocking the communist regime have been extremely prominent in eastern Europe. A classic Soviet joke runs as follows: one secret policeman asks another: "So, what do you think of the government?". His colleague looks around before replying, "The same as you, comrade", whereupon Policeman no. I declares, "In that case, it is my duty to arrest you". ${ }^{19}$ Is such a joke a protest against the regime? Not

14. Anton Zijderveld, Reality in a Looking Glass: Rationality through an Analysis of Traditional Folly (London 1982), p. 207: allowing the jester to make fun of the ruler was a way to show the absolute power of the monarch.

I s. Cf. the immunity position of the "joker" in various societies: Mary Douglas, "The Social Control of Cognition: Some Factors in Joke Perception”, Man (New Series), 3 (1968), pp. $36 \mathrm{I}-376,372$.

16. Christie Davies, Jokes and their Relation to Society (Berlin [etc.], I998), p. 176; Alexander Rose, "When Politics is a Laughing Matter", Policy Review, 59 (2001/2002), pp. 59-71.

17. Bakhtin, Rabelais, pp. $45^{2-454}$.

I8. Anton C. Zijderveld, "Jokes and Their Relation to Social Reality", Social Research, 35 (1968), pp. I86-31 I, 300-301, 306.

19. Rose, "When Politics is a Laughing Matter", p. 63. 
necessarily - much is in the eye of the beholder. Because of their ambiguity, jokes can often act as a relief from open or covert social pressures. Numerous studies of comparable jokes in the workplace have stressed the positive effect thereof for organizational harmony and for making tedious labour conditions bearable. Such jokes are often understood in the limited context of a factory or company only, and carry strong social, gendered, and/or ethnic boundaries. ${ }^{20}$

In extreme repressive regimes gallows humour acts as a psychological escape from the unalterable. ${ }^{21}$ Often, such jokes are self-deprecating, and serve to bolster fellowship among oppressed or marginalized ethnic groupings. ${ }^{22}$ Yet a joke that is funny when told within those communities stops being amusing when ruling, dominant, or arrogant classes or groups use a similar joke to stress the minority position of the oppressed. Indeed, humorologists emphasize time and again: humour is extremely strongly bound in social and cultural terms. Henri Bergson's famous theory on the group-characteristics of humour stressed: "Our laughter is always the laughter of a group. You would hardly appreciate the comic if you felt yourself isolated from others", and Konrad Lorenz stated: "Laughter forms a bond". ${ }^{23}$ The latter also pointed out to the aggressive, isolatingthe-other attributes of certain jokes. ${ }^{24}$ An illustration is the recent worldwide controversy about the publication of Mohammed cartoons in a Danish newspaper. ${ }^{25}$

It is not without reason that many ideologists of the political left regard humour and amusement as substitutes for the political action that should aim at change in societal settings. Indeed, numerous comedies on television strengthen existing stereotypes and show the inevitability of existing social

20. Kuipers, Good Humor, pp. 234-240; Janet Holmes and Meredith Marra, "Humour as a Discursive Boundary Marker in Social Interaction”, in Anna Duszak (ed.), Us and Others: Social Identities Across Languages, Discourses and Cultures (Amsterdam [etc.], 2002), pp. 377-400; Arthur Asa Berger and Aaron Wildavsky, "Who Laughs at What?", Culture and Society, 3 I (1994), pp. 82-86.

2 I. Antonin J. Obrdlik, "Gallows Humor: A Sociological Phenomenon”, American Journal of Sociology, 47 (1942), pp 709-716, 71 2.

22. Christie Davies, Ethnic Humor around the World: A Comparative Analysis (Bloomington, IN, I990); Anton C. Zijderveld, “Trend Report: The Sociology of Humour and Laughter”, Current Sociology, 31:3 (1983), pp. I-103, 51.

23. Both views quoted by Joseph Boskin, "The Complicity of Humor: The Life and Death of Sambo", in John Morreall (ed.), The Philosophy of Laughter and Humor (Albany, NY, I987), pp. $250-264,254$.

24. See also Oscar Verkaaik, "Fun and Violence: Ethnocide and the Effervescence of Collective Aggression”, Social Anthropology, I I (2003), pp. 3-22.

25. Giselinde Kuipers, "Het eerste transnationale humorschandaal. De Mohammed-cartoons en de mondialisering van de humor", Sociologie, 2 (2006), pp. 46I-466. For an overview of the variety in reactions on the Muhammad-cartoons, see: http://en.wikipedia.org/wiki/The_ Jyllands-Posten_controversy (accessed 8 January 2007). 
structures, thereby maintaining them. ${ }^{26}$ Humour in itself never changes circumstances. In addition, humour may even lessen discontent among the oppressed, which might inhibit the mobilization into action. In this regard, jokes are often viewed as safety valves, just as the early modern authorities regarded carnival and charivari. ${ }^{27}$ Yet humour can also serve social protest. Criticism and joy went extremely well together in the student movements of the I960s in the Western world. Playful acts were used widely as a technique in numerous non-violent protests; students explored the power of humour to attract media attention and to disarm the authorities. ${ }^{28}$

Similar strategies can be used on the shopfloor. In research on workplace jokes, the recent trend is to see subversive characteristics therein. Workplace jokes are not only simply safety valves; such jokes can also help the development of an attitude that stands in contrast to managerial values and priorities. ${ }^{29}$ In a Brazilian telecommunications company, for example, satire was expressed in a union newspaper that featured cartoons with characters like "Powerful Little Chief" - an autocratic manager with a little black moustache and a Nazi-uniform - and "Vaselineman" - a junior manager who claims to sympathise with the employees but who is obsessed with power and easily defers to senior management. ${ }^{3 \circ}$ In a British call centre, the following anecdote was told over and over again (and embellished, without doubt). One employee in the French section continued talking into the phone in French after the customer had hung up: "Thank you very much for calling. We will send someone round to kill your wife and family". The manager who happened to stand within earshot was humiliated in front of the other employees as the employee reported to his manager on the enormous success of this specific call. In another call centre, management was ridiculed by posters and flyers with texts like:

Are you lonely?

Having to make decisions?

Rather talk about it than do it?

Then why not

HOLD A MEETING

You can: Get to see other people

26. Murray S. Davis, What's So Funny? The Comic Conception of Culture and Society (Chicago, IL, I993), p. 3II; comedy's political implications are paradoxical - it makes radical and conservative statements at the same time.

27. Zijderveld, "Trend Report", p. 57. I thank Christie Davies for sharing his thoughts on this subject.

28. Davies, Jokes and their Relation to Society, p. 3 I I.

29. See also Janet Holmes and Meredith Marra, "Over the Edge? Subversive Humour between Colleagues and Friends", Humor: International Journal of Humor Research, is (2002), pp. $65-87$.

30. Suzana B. Rodrigues and David L. Collinson, "Having Fun? Humour as Resistance in Brazil”, Organization Studies, I6 (1995), pp. 739-768, 751-752. 
Sleep in peace

Offload decisions

Learn to write volumes of meaningless notes

Feel important

Impress (or bore) your colleagues

And all in work time!

[Followed by a photograph of the managing board in a meeting]

"MEETINGS"

\section{The Practical Alternative to Work ${ }^{3}$}

In these cases, the use of humour ended up in supporting the local tradeunion activists. Such can hardly be called "safety valves" any more: indeed, the double effects are difficult to separate.

As a communication strategy, humour belongs to the rich treasury of the instruments of politics and can be used in political protest. In early modern England, radicals regarded "ridicule and derision, mocking and playing the fool" as great polemical instruments. ${ }^{32}$ Jokes often weaken the defences of an audience and render the listeners more amenable to persuasion. 33 These tactics can be used by those in power too. But for those engaged in social protest from below, it is important to realize that "Joking often cuts through great obstacles better and more forcefully than being serious would". ${ }^{34}$ Criticism expressed in a joking manner is more difficult to refute by "rational" arguments. Authority and power can melt, as the invitation to laugh with one another appeals to all-human feelings and breaks down "official" barriers. As such, humour certainly constitutes one of the "weapons of the weak".35

\section{FRAMES, COLLECTIVE IDENTITIES, AND EMOTIONS}

In this respect the notion of "framing" is of interest, a concept used widely by social movement theorists nowadays. It refers to how a situation is interpreted by those engaged in social protest. ${ }^{36}$ Ideology counts, but

3 I. Phil Taylor and Peter Bain, “'Subterranean Worksick Blues': Humour as Subversion in Two Call Centres”, Organization Studies, 24 (2003), pp. I487-1 509, I 499.

32. Christopher Hill, The World Turned Upside Down: Radical Ideas During the English Revolution (Harmondsworth, 1975), p. 282.

33. John C. Meyer, "Humor as a Double-Edged Sword: Four Functions of Humor in Communication", Communication Theory, I0 (2000), pp. 310-331, 324.

34. Horace, quoted by Francis Hutcheson, "Traditional Theories of Laughter and Humor", in Morreall, Philosophy of Langhter and Humor, pp. 26-40, 35.

35. Humour seems very much in line with the other "weapons of the weak" of gossip and minor sabotage; see James Scott, Weapons of the Weak: Everyday Forms of Peasant Resistance (New Haven, CT, 1985 ).

36. The term refers to Erving Goffman's Frame Analysis: An Essay on the Organization of Experience (New York, 1974). On the concept of frame, see Hank Johnston, "Verification and Proof in Frame and Discourse Analysis", in Bert Klandermans and Suzanne Staggenborg (eds), 
framing is different from ideology: agents of the social movement have to define and articulate the position of the actors involved. They have to translate ideological beliefs into an existing, practical framework, giving events and experiences meaning so that they are connected with each other. A prescription of how to solve the problem also constitutes part of the framing process. Through framing, particular events and elements are also rated as more important than others. For example, William Gamson pointed to the importance of bringing "injustice" to the forefront in the framing of collective action. ${ }^{37}$

Framing is a way to link interests to social action. A fine example of humorous framing is the name giving to MADD, "Mothers Against Drunk Driving". The abbreviation itself is funny and catches the attention, whereas the initials provide a further framing of the protest. The term "Mothers" calls into being the protection of the powerless (children), "Against" with a capital A signifies anger and moral outrage, whereas "Drunk Drivers" stand for those acting socially irresponsibly and out of control..$^{8}$ Successful framing is of enormous importance for social movements, as it furthers the processes of resource mobilization. ${ }^{39}$

Alongside framing, the last decade has witnessed increased attention to the concept of "collective identity" in social movements. $4^{\circ}$ Charles Tilly showed how, during the nineteenth century, British protesters identified themselves increasingly as "supporters of [...], opponents of [...], members of $[\ldots]$, each defining a position with respect to actions by constituted authorities". With the rise of such collective identities, other ties weaken, such as with neighbourhood or family..$^{\text {I }}$ Collective identities also include

Methods of Social Movement Research (Minneapolis, MN [etc.], 2002) pp. 62-91; David A. Snow, E. Burke Rochford Jr, Steven K. Worden, and Robert D. Benford, "Frame Alignment Processes, Micromobilization, and Movement Participation", American Sociological Review, $5 \mathrm{I}$ (1986), pp. 46I-48I; Robert D. Benford and David A. Snow, "Framing Processes and Social Movements: An Overview and Assessment", Annual Review of Sociology, 26 (2000), pp. 6I I 639, 6r4. See, for a historical application of the concept: Michiel Baud and Rosanne Rutten, "Introduction", in idem (eds), "Popular Intellectuals and Social Movements: Framing Protest in Asia, Africa, and Latin America", Supplement I2, International Review of Social History (Cambridge, 2004), pp. I-I 8.

37. William Gamson, "Constructing Social Protest", in Hank Johnston and Bert Klandermans (eds), Social Movements and Culture (Minneapolis, MN, 1995) pp. 85-106, 9off.

38. James M. Jasper, "The Emotions of Protest: Affective and Reactive Emotions in and around Social Movements", Sociological Forum, I 3 (1998), pp. 397-424, 4I 2, referring to the study of Gusfield (1987).

39. On the concept "mobilization of resources", see Charles Tilly, From Mobilization to Revolution (Reading, MA, 1978).

40. This has undoubtedly been furthered by the "discursive turn" in the social sciences; see Roger V. Gould, "Historical Sociology and Collective Action", in Julia Adams, Elisabeth S. Clemens, and Ann Shola Orloff (eds), Remaking Modernity: Politics, History, and Sociology (Durham [etc.], 2005), pp. 286-299, 296 ff.

4I. Charles Tilly, Popular Contention in Great Britain, 1758-1834 (Cambridge, MA [etc.], I995), pp. $378-379$. 
and refer to the style of protest, repertoires of action, forms of organization, degree of moderation or radicalism, strategies and claims, and the use of certain terms. All in all, they distinguish "us" from "them", from opponents and/or from the community at large. Throughout, the construction of collective identities is facilitated by the existence of positive feelings towards other activists in the group..$^{42}$

An example of a strong collective identity bolstered by humour is the separatist movement of the Canadian west against the federal government in Ottawa in the early I980s. As a strategy to mark the boundaries of the in-group and the out-group, cheap marketable commodities were developed, such as bumper stickers with "The West Needs Ontario, Quebec and Trudeau Like a Fish Needs a Bicycle" or baseball-caps and T-shirts with "Republic of Western Canada". These items served as a source of camaraderie among those involved in the conflict. The humorous aspect lies in the fact that no-one could be certain whether such items conveyed a serious message or whether the wearer was just making fun of the idea. Meanwhile, the point was made nevertheless. ${ }^{43}$ In a more radical fashion, the Muhajir Quami Movement (MQM) of the I980s in Pakistan turned to aggresive humour in its aim to mobilize supporters. Through satire and grotesque exaggeration its public gatherings exploited existing ethnic and religious stereotypes, and succeeded in attracting numerous uprooted and marginalized youngsters in this way. ${ }^{44}$

Yet humour that furthers a collective identity is often limited to the already established "in-group" only. ${ }^{45}$ Louis Armstrong, the famous black jazz musician, related in his performances to the tradition of the African trickster and filled his record, "Laughin Louie", with numerous nonsense words - but much was only understandable to the black music community. Some of his jokes carried to a wider audience, in particular when referring to his colour, such as this joke: "Can God be black like me? My God!" 46

The African-American comedian Dick Gregory exploited the power of humour that is understood by variegated communities. Some passages in From the Back of the Bus (1967) are telling: "Personally, I like Negroes. I like them so much, I even had them for parents", or "The NAACP [National Association for the Advancement of Colored People] is a wonderful organization. Belong to it myself. But do you realize if

42. Francesca Polletta and James M. Jasper, "Collective Identity and Social Movements", Annual Review of Sociology, 27 (2001), pp. 283-305, 285, 292.

43. Harry Hiller, "Humor and Hostility: A Neglected Aspect of Social Movement Analysis", Qualitative Sociology, 6 (1983), pp. 255-265, 262.

44. Verkaaik, "Fun and Violence", p. I4.

45. On the integrating power of humour, see Zijderveld, "Trend Report", p. 47.

46. Frank A. Salamone, "Laughin' Louie: an Analysis of Louis Armstrong's Records and its Relationship to African-American Musical Humor”, Humor, I5 (2002), pp. 47-63, 55. 
tomorrow we had complete integration, all them cats would be outta work?" 47 By using the white-people idiomatic, denigrating way of talking, his message was loud and clear to all blacks who had heard such remarks all too often. Also, by taking up the issue of "complete integration" in a joking way, Gregory helped to release the tension related to that issue while engendering thought of integration as a possible future. His regular performances on television in the I 960 s undoubtedly raised the pride and self-consciousness of black Americans.

In studying the framing of protest and the furthering of collective identities, social scientists have become aware of the role of emotions again. ${ }^{8}$ Some forty or fifty years ago, social scientists regarded emotions as a natural concomitant to (unruly) crowd behaviour. Strongly influenced by Freudian insights, emotions were perceived in a pejorative way, mostly as negative, generally arising from specific personal internal contradictions, such as frustration. ${ }^{49}$ Most historical sociologists of the I970s and I980s looked upon emotions as irrational and left them aside while they concentrated on studying social structures, available resources, and societal conditions. ${ }^{50}$ For a couple of decades emotions dropped out of sight. The dominant paradigm was to explain behaviour in rational terms - even though not all researchers were adherents of methodological individualism, the impact of Mancur Olsons's work was strong throughout. ${ }^{\text {I }}$

Since the I990s, though, social scientists have not any more viewed emotions as antithetical to rationality. Frustration, fear, anger, alienation, and joy are taken into serious consideration. Emotions are not linked solely to personal psychologies, such as in the I960s, but are related to social networks, shared cultural meanings, and collective identities. ${ }^{52}$ Pride

47. Nancy Levi Arnez and Clara B. Anthony, "Contemporary Negro Humor as Social Satire”, Phylon, 29 (1968), pp. 339-346, 34I, quoting Gregory. He also ran for President of the United States in 1968. For some of Dick Gregory's most recent activities, see http://www.dickgregory. $\mathrm{com} /$ (accessed 6 January 2007).

48. A strong stimulus for taking emotions seriously was exerted by feminists and those studying the womens' movement, as women were especially susceptible to the allegation by their opponents that they were acting on "emotional" (i.e. irrational) grounds; see Jeff Goodwin, James M. Jasper, and Francesca Polletta, "The Return of the Repressed: The Fall and Rise of Emotions in Social Movement Theory", Mobilization, 5 (2000), pp. 65-84, 74-75.

49. Ron Aminzade and Doug McAdam, "Emotions and Contentious Politics", in Ronald R. Aminzade et al., Silence and Voice in the Study of Contentious Politics (Cambridge, 2001), pp. 14-50, 23; Goodwin, Jasper, and Polletta, "The Return of the Repressed", pp. 66-69; Craig Calhoun, "Putting Emotions in their Place", in Goodwin, Jasper, and Polleta, Passionate Politics, pp. $45-57,46$.

50. Julia Adams, Elisabeth S. Clemens and Ann Shola Orloff, "Introduction: Social Theory, Modernity and the Three Waves of Historical Sociology", in idem, Remaking Modernity, pp. $\mathrm{I}-72$, I $5 \mathrm{ff}$.

5. Mancur Olson, The Logic of Collective Action: Public Goods and the Theory of Groups (Cambridge, MA, I97I).

52. Jasper, "The Emotions of Protest", p. 398. 
has become an important emotion in studies dealing with Black Power or the gay and lesbian movements. Emotions are nowadays even regarded as essential to getting a social movement started. Alberto Melucci, above all, studied the "emotional investments" during mobilization processes. 53

A point of debate is, of course, whether humour can be counted among emotions. Most social scientists studying emotions in social movements stress the more negative feelings - fear, anger, anxiety, moral shock. ${ }^{54}$ Humour or laughter is not always counted as an emotion. 55 A recent trend among humorologists is to use the term "mirth" or "amusement" which accompanies humour, with an impact on "mood", as "a weak intensity emotion". Moods are regarded as lasting longer than emotions, having less disturbing effects. ${ }^{56}$ Laughter produces pleasure - this is indeed a "shortterm" response, yet can be crucial in stressful situations during political confrontations. ${ }^{77}$ Furthermore, such "short-term responses" contain a strong binding power that can have powerful repercussions in the longer term. The impact of humour (brought about by laughing with one another) can strengthen and forge long-term responses like feelings of affection, solidarity, and loyalty among activists. In this regard, laughing together has similar bonding powers like marching, dancing, or singing together..$^{8}$ Combining marching and humorous singing is an effective tactic to create solidarity, like chants during a demonstration, which often use the rhythm and accentuation of popular songs. Consider for example the funny composition by Joe Hill, the famous songwriter in the US civil rights movement at the beginning of the twentieth century, referring to a pitchfork that slipped "accidentally" into the cogwheels of the threshing machine as an act of sabotage: "Ta-ra-ra boom de ay! It made a noise that way, And wheels and bolts and hay went flying ev'ry way".59

Framing, the construction of a collective identity, and the study of emotions thus yield a rich vocabulary that will assist the contributions in

53. Alberto Melucci, “The Process of Collective Identity", in Johnston and Klandermans, Social Movements and Culture, pp. 4I-63, 45; on grievances in social movements, see also Bert Klandermans, "The Formation and Mobilization of Consensus", in Bert Klandermans, Hanspeter Kriesi, and Sidney Tarrow (eds), From Structure to Action: Comparing Social Movement Research Across Cultures (Greenwich, CT, I988), pp. 173-196, I79.

54. Jeff Goodwin, James M. Jasper, and Francesca Polletta, "Introduction: Why Emotions Matter", in idem, Passionate Politics, pp. I-26, I I.

55. John Morreall, "Humor and Emotion", in idem, Philosophy of Laughter and Humor, pp. 2I $2-224$.

56. Martin, Psychology of Humor, p. 273; Lambert Deckers, "Influence of Mood on Humor", in Willibald Ruch (ed.), The Sense of Humor: Explorations of a Personality Characteristic (Berlin [etc.], 1998), pp. 309-328, 31 I, 325 .

57. Martin, Psychology of Humor, p. I9.

58. Zijderveld, "Trend Report", p. 44; William McNeill, Keeping Together in Time: Dance and Drill in Human History (Cambridge, MA [etc.], 1996).

59. Gibbs M. Smith, Labor Martyr: Joe Hill (New York, 1969), p. 35. 
this volume. Yet humorous framing does not always prove to be effective. Much depends upon the "political opportunity structure", a notion that must be introduced here briefly too. Political opportunities are always partly structural, partly eventful; their analysis helps to explain the relative success of certain protest movements. For example, it is important to establish the degree of division among the ruling elites, the existence of other sympathizing groups, the stability of political alignments between rulers and ruled, and the capacity of the existing state structures. ${ }^{60}$ Political instability has always been a good "predictor" of collective action - the movements arising in eastern Europe after " 1989 " are a case in point. ${ }^{6 \text { I }}$ The existence of an independent "public sphere" should also be counted among "political opportunities", as it clarifies the possible scale of political criticisms and shows whether there is room for a particular type of humorous protest. ${ }^{62}$

Together, such insights - recent and less recent - from humorologists and sociologists help us to understand the role of humour in social protest in the past. True, social movements are not similar to social protest - the first refers to a group with a certain duration, whereas the second is rather limited as an event. Also, not all historical cases can profit from interviews, such a powerful tool for many a social scientist in trying to establish motives or emotions. Still, historians (Ah! How great to be an eclectic!) can profit from this body of research for the purposes of this volume: to establish how and when humour has served social protest in the past.

\section{THIS VOLUME}

The discussion above facilitates the further assortment of individual contributions to this volume. The first set of contributions is grouped under the name "Humour, Framing, and Resource Mobilization" - they show, above all, how humorous framing furthered the mobilization of activists and resources. Three articles follow which stress the interaction between "Satire, Protest, and the Public Sphere". The existence of a wider "public sphere" supports the development of criticism from below and

6o. Sidney Tarrow, Power in Social Movement: Social Movements, Collective Action and Politics (Cambridge, I994), pp. 8Iff.; Wayne te Brake, Shaping History: Ordinary People in European Politics, I 500-I700 (Berkeley, CA [etc.], I 998) p. I4; for a sociological account on cooperation and conflicts among elites in history, see Richard Lachmann, Capitalists in Spite of Themselves: Elite Conflict and Economic Transformations in Early Modern Europe (Oxford [etc.], 2002).

6I. S.N. Eisenstadt, "The Breakdown of Communist Regimes", in Vladimir Tismaneaunu (ed.), The Revolutions of 1989 (London, 1999), pp. 89-107.

62. Jürgen Habermas, The Structural Transformation of the Public Sphere (Cambridge, MA, 1989); Simon A. Gunn, "The Public Sphere, Consumption and Modernity: New Perspectives on the History of the English Middle Class", in A. Kidd and D. Nicholls (eds), Gender, Civic Culture and Consumerism: Middle-Class Identity in Britain I800-1950 (Manchester, 1999), pp. I $2-29$. 
allows the manipulation of the "audience" through satirical protest, above all by using the mass media. The third set of contributions relate to "Carnival Laughter and the Disarming of the Opponent", stressing the emotional leverage of humour to cut down existing bureaucratic and oppressive barriers. The fourth set concentrates on "Humour and the Construction of the Collective Identity in Social Movements", and shows the power of laughter in the formation of protesting groups. The last three articles are joined under the heading "Jokes, Social Protest, and the Wider Society" and demonstrate above all how political opportunity structures influence the effects of humour in social protest.

This volume begins with three articles that stress how humorous framing aided the mobilization of activists and resources. Thomas Olesen shows how the Zapatista movement in Mexico was able to communicate its aims and goals to a wider, even global, audience. The humorous anecdotes of Commandante Marcos served both as an invitation to join the movement at home and also established solidarity with sympathizers from quite distant communities at the same time. Part of Marcos's success was the self-deprecating character of the anecdotes: his kind of humour "reduced" the activists to "humans", encouraging identification with the Zapatistas worldwide. ${ }^{63}$ Yet humour does not need to be always selfdeprecating in order to be successful:

Michael Cohen analyses how another kind of humour helped to build up the socialist movement in the early twentieth-century United States. Radical cartoons served a class-conscious politics of laughter by attacking the opponent in a ridiculing way. Such images often proved a more direct communication method than written treatises. The aims and the common values of the socialist movement were communicated to the wider public through appealing and humorous drawings.

Cartoons also served to frame the discontent of the migrants from southern Italy who took up jobs in the automobile plants of Turin from the late i960s. Nicola Pizzolato studied the comic strips of Gasparazzo, which, in fact, contain severe criticism of the FIAT management and the wider capitalist society. ${ }^{6}$ In appealing to the shared experience of these southerners, this popular comic strip served to mobilize a marginalized group of workers in a wave of strikes that became known as the "Hot Autumn" in Italy.

The second group of articles emphasizes the use of satire. All three relate the success (or failure) of this instrument to the "readiness" of the "public sphere", that part of society which can discuss the pros and cons of the existing political establishment in a more or less open way. Christian

63. On the strength of self-deprecating humour: Zijderveld, "Trend Report", p. 5 I.

64. On comparable workplace cartoons, see Rodrigues and Collinson, "Having Fun?: Humour as Resistance in Brazil”, p. 756. 
Kuhn's analysis of the Herbrot-Buch, a collection of satires directed against an opulent and ostentatious mayor, shows the relevance of this public sphere as long ago as sixteenth-century Augsburg. By applying satirical inversions and well-known personifications from classical literature, this literary tradition constituted a powerful tool for social protest among the more literate early modern urban communities. Satire thus belonged to the established repertoire of channelling discontent.

Sammy Basu, however, shows that the success of such instruments was strongly dependent upon the political opportunity structure of the time. In seventeenth-century England the humorous protest of the Levellers was swamped in the much more morose political culture of the ever growing (and eventually dominating) Puritan political movement. ${ }^{65}$ Still, humour was vital in the early phases of the Leveller movement, above all in mobilizing popular support for the agenda of the protesters.

Shifting to a more recent past, the public sphere of twentieth-century Germany proved quite able to pay considerable attention to radical criticism. Simon Teune has studied the humour used by the student movement in the mockery of the "humourless" state. During court proceedings, the satirical comments and remarks of the members of the Kommune Eins attracted enormous public attention, resulting in a wider group of sympathizers. However, as political antagonisms sharpened after a student was shot dead during a demonstration, humour also disappeared from the repertoire of the activists: obviously, the political opportunity structure had altered.

The third group of articles stresses the power of carnival laughter in disarming the opponent. Lisiuna Romanienko shows how the Polish "Orange" Solidarity movement - a section with a strong base in Wrocław - used avant-garde absurdist traditions to ridicule the communist authorities. Their humour embarrassed the human beings behind the police shields and Soviet tanks and boosted the morale of the protesters at the same time. The success of this protest was furthered by the low state capacity of the Polish regime.

Comparable playful tactics were deployed by the Italian "I977" movement, above all in its conflict with the humourless traditional leftist movement, as Patrick Gun Cunninghame demonstrates. The radicals represented a group of marginalized youngsters; they belonged to a broader social movement whose repertoire also included armed violence, but their main tactics were theatrical and individual actions that were highly successful in gaining publicity for their political opinions. Last, but certainly not least, Anna Lundberg analyses the case of the carnival 
parades of the gay and lesbian movement in Sweden. These joyful events present possible other-views-of-the-world, and mock typical heterosexual norms, using humorous inversions of gendered roles. While inviting the public to laugh with them, the participants in these parades aim to establish peaceful change in the existing homophobic discourse.

Many of the articles mentioned above deal with the role of humour in the construction of the collective identity of the protesters, yet the following set of articles render that aspect a crucial point in their arguments. Kirsti Salmi-Niklander describes the oral literary tradition of a certain group within the Finnish youth movement after World War I by studying their handwritten newspapers. Irony, parody, and satire strengthened the bonds between the participants of this "conversational community", allowing its members to play with their responsibilities as activists and with the ideals of the labour movement.

How humour serves as a "weapon of the weak" is shown in the next contribution by Nghiem Lien Huong, focusing on the workplace jokes in a garment factory in Vietnam. She concludes that these jokes actually constituted a covert resistance to the management. Humour proves a particular effective instrument when no trade union is able or willing to pick up the complaints. Throughout, these jokes strengthened solidarity among the workers in such repressive labour conditions. ${ }^{66}$

Likewise, Australian soldiers in the British army during World War I had few official channels to voice their protests about living conditions, as shown in Nathan Wise's contribution. Jokes, cartoons, and theatrical performances served extremely well to get the message to their officers. At the same time, these tactics furthered the specific "citizen-identity" of the soldiers. Cristina Flesher Fominaya shows the great impact of humour in her study of the Autonomous Groups in Madrid in the I990s. Above all, jokes stressed their particular identity as distinct from all other existing political structures, including those of the traditional left-wing movement: the latter were predominantly "vertical" and "closed", whereas they were "horizontal" and "open".

The last group of articles turns to the use of humour in social protest in relation to the political framework of the wider society. In early twentiethcentury Britain, the male-dominated culture made fun of the suffragettes, but Krista Cowman demonstrates how the latter proved highly ingenious in turning the criticism deployed against them into amusing inversions. This "counter-humour" regularly served as a political tactic in silencing hostile male hecklers who disrupted their meetings, while they also

66. See, for another study on work-place jokes and the strengthening of collective identity of the workers: Shankar Ramaswami, "Masculinity, Respect, and the Tragic: Themes of Proletarian Humor in Contemporary Industrial Delhi”, in Rana P. Behal and Marcel van der Linden (eds), Coolies, Capital, and Colonialism: Studies in Indian Labour History, Supplement I4, International Review of Social History (Cambridge, 2006), pp. 203-228. 
deepened the ties between the activists within the British Women's Social and Political Union. ${ }^{67}$

Patrick Merziger's contribution turns to a different setting: Nazi Germany. For quite some time historians assumed that the regular recurrence of the so-called "whispered joke", a joke ridiculing the repressive regime which could not be expressed loudly, pointed to a widespread resistance to the German authorities. To the contrary, the author demonstrates that the "whispered joke" was even welcomed by those in power. In fact, humour - including these jokes - served the general desire to "laugh together". Finally, Christie Davies links up well with the previous contribution in stating that the numerous jokes that circulated in the Eastern European communist countries were, in themselves, no proof or sign of existing opposition. Still, throughout the I 980 s, the vast number of these jokes did undermine the general legitimacy of the regimes, thereby contributing to the speed of the collapse that came about in 1989 .

\section{CONCLUDING}

It is time now to return to the questions posed at the start of this introduction, although the actual answers can only be tentative at this point. The first question concerned the problem of under what conditions laughter could serve the causes of the protesters. These conditions turned out to vary strongly, from the open globalization settings of the Zapatistas to the authoritarian garment factory in Hanoi. No "rules of thumb" can be applied, such as "humour is more effective in democratic societies", or "fear and threat exclude humour as a communication tool". As Basu shows, the Puritan government in early modern England suppressed all kinds of laughter in society, rendering the humorous protests by the Levellers extremely difficult. Yet Merziger's contribution conveys the message that even such an authoritarian regime as the Nazis in Germany allowed laughter - even though some types of humour were obviously favoured above others. In eastern Europe during the communist era, the totalitarian character of the societes did not prevent the existence of a sparkling humorous culture either.

Yet one condition must be met before humour can be utilized in social protest: the condition of a pre-existing collective identity, or a strict setting of the jokes. ${ }^{68}$ Humour never starts just out of the blue. For cartoons to be successful, the background of the paper should be unambiguous. In early

67. Thereby defying the general idea that feminists have no sense of humour; see also Nancy Walker, "Do Feminists Ever Laugh? Women's Humor and Women's Rights", International Journal of Women's Studies, 4 (1981), pp. I-9.

68. See also Davies, Ethnic Humor around the World, p. 318. 
modern Germany, the repertoire of satire was so well known that a curious "complaint of the garden" was sufficient to ridicule the mayor. The gays and lesbians in Lundberg's contribution already enjoyed a strong collective identity before they decided to parade. The Finnish youngsters studied by Salmi-Niklander knew each other well before they wrote their funny stories. The examples of Merziger and Davies show that without a certain existing collective identity, humour has very little direct impact on social protest.

The more "risky" uses of humour, depending upon favourable reactions from the wider society, benefit enormously from the existence of a salient public sphere, with a mass media able to cover the activities. Teune stresses the innovative character of the satirical comments of the German student movement, but they were all well covered by newspapers and television. That such attempts to use humour are risky is shown in the cases where the public (and the journalists!) did not understand or appreciate the message (see the contributions by Flesher and Gun). Yet Olesen found that the humour of the Zapatistas could transcend numerous national and cultural barriers, because an educated middle class in the "Westernized" world existed that had learned to appreciate this playful kind of repertoire. Indeed, particularly in our present-day societies, that respond positively to those "having a sense of humour", this is an advantage that can be exploited by protesters. During the "alter-globalist" protests in Seattle, for example, when the World Trade Organization met in November 1999, media coverage of the absurd "turtle brigade" (protesters in turtle costumes, positioning themselves as ancient repositories of wisdom) was much larger than that of the more "serious" protests. ${ }^{69}$ Because of its surprising character, humour is always different, and enjoyable news is always to be preferred to predictable news. ${ }^{70}$

The second question concerned how humour was used by the protesters, and in this respect the role of humour as a communication tool should be stressed. Humour helped in getting the message across, assisted in pointing to salient points, and attracted attention to adverse conditions. In short: framing! Cartoons proved valuable tools as they ridiculed and criticized opponents at the same time. The images also helped to bring the message to less literate groups. Undoubtedly, humorous framing rallied activists and means.

Humour served the protesters in another way. A carnivalesque use of humour proved enormously effective in getting the message to the wider public, because of its emphasis on the shared human background of oppressors and oppressed. At the same time, humorous acts often

69. Lane Brunner, "Carnivalesque Protest and the Humorless State", p. I47.

70. On the importance of media coverage for social movements, see Gamson, "Constructing", pp. 8 5ff. Of course, journalists also want to share the jokes they have heard with "their" public. 
supported the morale of the protesters. Fydrich, comically known as the "Major" in the Polish anti-communist protest movement (see the contribution of Romanienko) stated that the "Orange happenings" were ways to "learn opposition": "The Wrocław street slowly ceases to fear, and through participation in the fun, people learn to support more serious [protest [...] and slowly the] fear of detention [...] evaporates." ${ }^{\prime 1}$ Almost all the contributors to this volume point to the positive role of humour in strengthening an existing collective identity.

The last question, to what degree humour has been an effective tool for contentious movements, is probably the most difficult of all to establish. In most cases, humour seems to have added to existing successes. Humour proved quite a powerful tool for the Zapatistas, for the US radical movement, for the southern Italian FIAT workers, among others. For some groups, humour constituted the communication method per se they could not do without it: the Italian "I 977 " movement described by Gun, the Madrid Autonomous Groups studied by Flesher, or the Finnish youngsters in the contribution of Salmi-Niklander. In some cases humour seemed the only possible communication method left, such as for the Vietnamese garment workers or the Australian soldiers. This should be attributed to the flexible character of humour: when the authorities act in a repressive way, the protesters can always refer to the excuse they were "only" joking; meanwhile, the critical points are made, nevertheless.

The effects of the use of humour lasted longer or shorter, according to the circumstances and the political opportunity structure. Indeed, humour is extremely strongly context-bound. After the end of World War I, the specific humorous culture of the Australian citizen-soldiers evaporated. But almost all the cartoons in Cohen's contribution still appeal to the present-day critics of capitalist structures, and Gasparazzo is also quite a recognizable creature nowadays. The satire against the Augsburg mayor must have acted in the longer term too, as a warning to political aspirations of the nouveaux-riches. The parades in Sweden boosted solidarity among the gay movement, and the women activists of the WSPU also supported each other through their jokes.

Even after all these "positive results", I do not wish to deny the "safetyvalve" theory totally. The enormous body of political jokes in eastern Europe did not relate directly to a mass critical movement (Davies), and neither were the "whispered jokes" of the Nazi regime linked to a protest movement (Merziger). Still, some jokes like these carried a higher "resistance" attitude than others: for example, the joke that stressed the long line of people wishing to murder Gorbachev (Davies, in this volume), or the hanged hen found by a Gestapo agent in a village in Czechoslovakia 
during World War II with a sign on her neck: "I'd rather commit suicide than lay eggs for Hitler". $7^{2}$

After such a varied account of humour used in all these different settings of social protest, I wish to stress that it is wise to remain aware of the possible pitfalls in the study of humour and emotions in social movements. For some protesters perhaps, jokes are appreciated only because one feels compelled to do so. Furthermore, a joke can bring people together but it can also shock, hurt, and exclude. Humour can bind but also divide when a joke is perceived as unjust or rude, it may well just have a countereffect - with the result that some groups may decide not to join the movement after all. The impact of humour in such "negative cases" has not been studied in detail as yet. Moreover, the majority of the studies in this volume are drawn from the present-day Westernized world, which may well restrict the conclusions to only a minor part of the globe..$^{73}$

Despite these warnings, this volume shows that humour and social protest are by no means dedicated "class enemies"; they can certainly operate as "comrades". Hopefully, these contributions will provide a starting point of thinking more often about the valuable relationship between humour and social protest. Over sixty years ago, George Orwell stated: "Each joke is a tiny revolution". ${ }^{74}$ Surely "tiny" indeed, as humour cannot change structures by itself. Yet this volume shows above all the positive role of humour in the framing of social protest. And one particular aspect of humour should not be overlooked: through jokes "the unimagined" is made "imaginable". What can count as "only joking", may well turn into reality later on.

72. Obrdlik, "Gallows Humor", p. 71 5.

73. This bias towards the Westernized world is also present in most studies on social movements: see Bert Klandermans, Suzanne Staggenborg, and Sidney Tarrow, "Conclusion: Blending Methods and Building Theories in Social Movement Research", in Bert Klandermans and Suzanne Staggenborg (eds), Methods of Social Movement Research (Minneapolis, MN [etc.], 2002), pp. 314-350, 3I 5 .

74. George Orwell, "Funny but not Vulgar", Leader, 28 July i945 - also available at http:// www.nonsenselit.org/Lear/essays/orwell_2.html (visited 8 January 2007). 